\title{
Qualified Audit Reports of Local Authorities in the Northern States of Malaysia
}

\author{
MOHAMMAD AZHAR IBRAHIM \\ ENGKU ISMAIL ENGKU ALI \\ SYED SOFFIAN SYED ISMAIL \\ ZAINOL BIDIN \\ Faculty of Accountancy \\ Universiti Utara Malaysia
}

\begin{abstract}
The reliability of information presented in the financial reports of local authorities is of utmost importance to enable the public to measure their performance in terms of efficiency and effectiveness in using public resources. The task to provide such an assurance lies with the Auditor General, who has been entrusted to enforce the auditing compliance regulations. A certificate in the form of "unqualified," "qualified," "adverse," or "disclaimer" accompanied by a report on the financial affairs of the local authorities concerned will be issued after the Auditor General completes the audit of the local authorities' financial statements. Our study on 14 local authorities comprising municipal and district councils in the Malaysian States of Perlis, Kedah and Penang found that the Qualified Certificate is the common type of audit certificate issued to the local authorities concerned during the period 1997-2001(inclusive of both years). Discrepancies in "Fixed Assets Register" ranked first among the audit incidents that led towards non-compliance to the audit procedures. This was followed by discrepancies in "Other Receivables" and "Cash Flow Statements" which ranked second and third positions respectively. Our finding also shows that size does not grant any advantage to the bigger local authority in reducing the number of audit incidents.
\end{abstract}

Keywords: Local authorities, financial reporting, accountability, audit incidents.

\begin{abstract}
ABSTRAK
Kebolehpercayaan terhadap maklumat yang dipersembahkan dalam laporan kewangan pihak berkuasa tempatan adalah penting bagi membolehkan orang-ramai mengukur prestasi mereka dari segi keefisian dan keberkesanan dalam penggunaan sumber. Tugas bagi memastikan kebolehpercayaan terhadap maklumat tersebut dipikul oleh Ketua Audit Negara (KAN), iaitu pegawai yang dipertanggungjawab untuk menguatkuasakan peraturan-peraturan berkaitan pematuhan prosedur audit. Sijil dalam bentuk "tanpa teguran (unqualified)," "berteguran (qualified)," "menafikan (adverse)," atau "bertentangan (disclaimer)" disusuli dengan laporan berhubung kedudukan kewangan pihak berkuasa tempatan berkenaan akan dikeluarkan setelah KAN selesai mengaudit laporan kewangan pihak berkuasa tempatan terbabit. Kajian ke atas 14 pihak berkuasa tempatan merangkumi majlis perbandaran dan majlis daerah di negeri-negeri Perlis, Kedah dan Pulau Pinang mendapati Sijil Berteguran adalah jenis sijil audit yang kerap dikeluarkan untuk tempoh 1997-2001. Daripada kesemua teguran audit yang menjurus kepada pengeluaran sijil berteguran yang melambangkan ketidakpatuhan prosedur audit, "Daftar Aset Tetap" menduduki tempat pertama disusuli "Lain-lain Penerimaan" dan "Penyata Aliran Tunai" iaitu masing-masing ditempat kedua dan ketiga. Hasil kajian juga mendapati bahawa saiz tidak menberikan sebarang kelebihan kepada pihak berkuasa tempatan yang lebih besar dalam mengurangkan bilangan teguran audit.
\end{abstract}




\section{INTRODUCTION}

Financial report is one of the main sources of information used by the public to measure the performance of a local authority. Thus, the reliability of the financial information presented is important so as to ensure that the public assessment on the efficiency and effectiveness of the local authority in using the public resources is fair and valid. Reliability assurance of the financial information is made possible through auditing and for public sector, the responsibility to provide such an assurance lies with the Auditor General as provided under Section 60(1) of the Local Government Act 1976 (LGA). The Auditor General, having completed the task of auditing the financial statements, would issue a "disclaimer," "unqualified," “adverse," or "qualified" certificate to indicate his view of the financial information presented. This certificate is issued together with a report on the financial affairs of the local authority concerned as required by Section 60(2) of the LGA.

A disclaimer certificate, according to the Malaysian Approved Standards on Auditing (MASA) AI 700, is issued when the possible effect of a limitation on scope of the auditor's work is so material and pervasive that the auditor has not been able to obtain sufficient appropriate audit evidence and accordingly is unable to express an opinion on the financial statements. An unqualified certificate on the other hand, is issued when the auditor concludes that the financial statements give a true and fair view and are presented in accordance with the identified financial reporting framework. An adverse certificate is issued when there is a disagreement with the management regarding the acceptability of the accounting policies selected, the method of their application or the adequacy of financial statement disclosures. The effect of a disagreement is material and so pervasive that the auditor concludes that a qualification of the report is not adequate to disclose the misleading or incomplete nature of the financial statements. In the case where the auditor is able to express opinion on the financial statement but the statement lacks disclosure of certain significant financial information, a qualified certificate will be issued; and the auditor's report should describe the limitation and indicate the possible adjustments to the financial statements that might have been determined to be necessary had the limitation not existed (MASA-AI 700 p. 9).

As identifying the limitations that lead towards the issuance of a qualified certificate is the main concern of the study, we establish our research question as follows:

What are the reasons for the issuance of a qualified certificate to the local authorities in the Malaysian States of Perlis, Kedah and Penang?

This paper is arranged to firstly discuss the justification for the study in Section 2 followed by the objectives outlined in Section 3 . Section 4 contains a review of existing literature, while Section 5 details the methodology used to carry out the study. The findings of this study are reported in Section 6. Section 7 concludes the paper by stating the limitations of the study and making suggestions for future research.

\section{JUSTIFICATION FOR THE STUDY}

The reliability of the financial information presented is important for it reflects on the accountability of an organisation. Previous studies related to the financial reporting of the local authorities in Malaysia suggested that the reports presented are generally of poor quality. In these studies, Nailah (2001) focused on the types of report issued to the local authorities in Malaysia from 1998-2000; Emelin and Asmah (2002) focused on the quality of financial reports concerning eight local authorities in Malaysia from 1989-1997; whilst Emelin and Asmah (2004) concentrated on the types of report issued and audit incidents that existed in the certificates of selected local authorities in the states of Perak, Selangor, Negeri Sembilan, and Sarawak for the period 1990-2000. However, we are not aware of any study that accordingly specifies and ranks in terms of frequency all items that breach the audit compliance of the local authorities' financial statements (refered to as audit incidents), leading to the issuance of qualified audit certificates. The 
lack of such a study motivates us to carry out this research with the hope that it would act as a launch pad for more rigorous research in improving the level of audit compliance of local authorities' financial reporting in Malaysia.

\section{OBJECTIVES OF THE STUDY}

This study attempts to achieve the following objectives:

(i) to identify the types of audit certificates issued by the Auditor General to the local authorities in the area of study,

(ii) to identify the audit incidents that lead to the issuance of a qualified audit report, and

(iii) to determine whether there is any significant effect of size of the local authority in terms of degree or frequency of audit incidents.

\section{REVIEW OF LITERATURE}

Previous studies concerning local authorities in Malaysia revealed the worrying conditions of their financial reporting standards. Emelin and Asmah (2002) found that the financial reports issued were of poor quality stating that the lack of accounting skills and insufficient qualified staff as the most probable cause. Nailah (2001) posited that the weaknesses occurring in local authorities, especially in the preparation of accounts and in the management of financial affairs, are of a recurrent nature, since only 149 (around 41\%) unqualified certificates or clean reports were issued to the local authorities during the years 1998 to 2000 , as compared to the 213 qualified or disclaimer certificates issued. A recent study by Asmah and Emelin (2004) involving 51 local authorities in the states of Perak, Selangor, Negeri Sembilan, and Sarawak for the period 1990-2000 suggested that most of the financial reports have not achieved the expected reporting standards. Further review of literature reveals the existence of a relationship between financial reporting and accountability as well as good governance.
Financial Reporting and Accountability

Financial reporting of the local authorities reflects on the accountability of public funds that they have been entrusted with and needs to comply with the legislature's requirements. It is a comprehensive overview of the Government's financial characteristics of performance and financial position that is disclosed by a business entity. Higson (1996) stated that financial reporting, unlike financial statements that are presented to provide a true and fair view of the organisation's financial position, provides other information in addition to the information related to the financial statements.

Indeed, the Governments' annual reports, besides the budget papers, are important and recognised generally as key documents in the discharge of accountability to external users, primarily the legislature, government watchdogs, creditors and the citizenry (Patton, 1992, Hyndman \& Anderson, 1995; Mahamad, 1998 and Radiah, Jamaliah and Noraini, 2001). In Malaysia, accountability issues are emphasised in the Federal Constitution 1957, Financial Procedure Act 1957 and Audit Act 1957. Accountability in the public sector is argued to be more crucial than in the private sector due to the involuntary nature of funding for governmental activities and the types of activities that are being funded (Kidwell, 1999; Nichol \& Taylor, 2001). Effective accountability in practice, according to Boyne and Law (1991), is virtually impossible without accurate information on the local authority's performance.

Accountability, according to Davison (2000), reflects high quality of work, encourages people to be diligent in their work and serves as a punishment platform for unachieved objectives. Nailah (2001) posited that accountability is the obligation to give answers and explanations concerning one's actions and performance to those with a right to require such answers and explanations. Ishak (1989) stated that public service accountability involves methods in which a public agency or a public official fulfils his/her duties and obligations, and that the public agency or officials are required to account for such actions. This strategy is meant to secure compliance with accepted standards to minimise the abuse of power 
and authority in the public sector. Ishak (1989) further argued that accountability is the fundamental pre-requisite element in preventing the abuse of delegated power and for ensuring that power is directed towards the achievements of broadly accepted national goals with the greatest possible degree of efficiency, effectiveness, probity and prudence.

\section{Financial Reporting and Good Governance}

Beside transparency, it is obvious that accountability is one of the factors that contributes towards good governance. In the public sector, good governance to Harris (1997) is about how the Government, boards and the parliament relate to one another in stewardship matters. Nailah (2001) posited that good governance ensures the effective and efficient collection of revenue as well as allocation of resources, better quality services, strict adherence to rules and regulations, and avoidance of waste and extravagance.

In 1999, Abdul Aziz, the former Deputy Secretary General of the Malaysian Ministry of Finance whilst commenting on the issue of governance, stated that "governance is the process and structure used to direct and manage the businesses and affairs of the company towards enhancing the business prosperity and accountability with the ultimate objective of realising long-term shareholder value, whilst taking into account the interest of other stakeholders."

Obviously, good governance is not just about accountability, but is important indeed for the prosperity of the local authority in enhancing government value.

\section{RESEARCH METHODOLOGY}

The study investigates the audit incidents of local authorities in the Malaysian states of Perlis, Kedah and Penang. The population for our study includes all local authorities in those three states that fit the criteria of local authority stated in Section 3 of LGA, namely a creature of the state (Mahamad, 1998: 16). Although there are 15 local authorities consisting of one (1) local authority in the State of Perlis, 12 in Kedah and two (2) in Penang
(Ministry of Housing and Local Government, we excluded from our list the local authority of Kulim Hi-Tech Industrial Park in Kedah for being the subsidiary of Kedah State Development Corporation, which is inconsistent with the definition of local authority outlined in Section 3 of the LGA. With the exclusion, the population for the study consisted of 14 local authorities as presented in Table 1. The local authorities concerned were visited to collect their annual reports for the years 1997-2001 and the auditor's reports within the annual reports were reviewed to identify the type of audit reports issued. The auditors' comments from all the qualified audit reports were scrutinised in order to identify the audit incidents reported in the comments. The frequencies of each type of audit incidents were totalled and grouped according to the type of local authority. The data were analysed to provide an answer for our research question as well as to achieve the objectives of the study.

\section{FINDINGS}

Seventy (70) annual reports from 14 local authorities covering the period 1997-2001 were analysed for the study. The findings on the type of audit certificates received by the local authorities concerned are presented in Table 2 . When the audit certificate is not found in the annual report, it is categorised as "unavailable". It was found that slightly more than three quarters $(75.72 \%)$ of the audit certificates issued were qualified, while the remaining certificates received by the local authorities concerned were either unqualified $(17.14 \%)$ or unavailable $(7.14 \%)$. Neither adverse nor disclaimer audit certificates were found to have been issued to any of the local authorities involved.

Table 3 represents the types of audit certificates issued to the local authorities concerned in terms of percentages. Overall, the qualified certificate appears to be the most frequent type of audit certificate issued to the local authorities in the Malaysian States of Perlis, Kedah and Penang for the years 1997 to 2000. It was found that the percentage of qualified certificates issued increased tremendously from 85.71 percent 
Table 1

List of Population

\begin{tabular}{llcc}
\hline Local Authorities & State & Type of Council & Location \\
\hline Penang Municipal Council & Penang & Municipal & Komtar Building \\
Seberang Prai Municipal Council & Penang & Municipal & Butterworth \\
Kangar Municipal Council & Perlis & Municipal & Kangar \\
Kota Star Municipal Council & Kedah & Municipal & Alor Star \\
Sungai Petani Municipal Council & Kedah & Municipal & Sungai Petani \\
Kulim Municipal Council & Kedah & Municipal & Kulim \\
Langkawi Municipal Council & Kedah & Municipal & Langkawai \\
Kubang Pasu District Council & Kedah & District & Jitra \\
Padang Terap District Council & Kedah & District & Kuala Nerang \\
Baling District Council & Kedah & District & Baling \\
Sik District Council & Kedah & District & Sik \\
Bandar Baru District Council & Kedah & District & Serdang \\
Yan District Council & Kedah & District & Yan Besar \\
Pendang District Council & Kedah & District & Pendang \\
\hline
\end{tabular}

a Upgraded to Municipal Councils since 2000

Table 2

Types of Audit Certificate Issued to the Local Authorities in Perlis, Kedah and Penang

\begin{tabular}{lrrrrrrr} 
Type of certificate & $\mathbf{1 9 9 7}$ & $\mathbf{1 9 9 8}$ & $\mathbf{1 9 9 9}$ & $\mathbf{2 0 0 0}$ & $\mathbf{2 0 0 1}$ & Total & Percentage \\
Qualified & 12 & 14 & 13 & 10 & 4 & 53 & 75.72 \\
Unqualified & 2 & 0 & 1 & 2 & 7 & 12 & 17.14 \\
Unavailable & 0 & 0 & 0 & 2 & 3 & 5 & 7.14 \\
\hline Total & 14 & 14 & 14 & 14 & 14 & 70 & 100.00 \\
\hline
\end{tabular}


Table 3

Types of Audit Certificate Issued to the Local Authorities in Perlis, Kedah and Penang (in percentages)

\begin{tabular}{lrrrrr}
\hline Type of certificate & $\mathbf{1 9 9 7}$ & $\mathbf{1 9 9 8}$ & $\mathbf{1 9 9 9}$ & $\mathbf{2 0 0 0}$ & $\mathbf{2 0 0 1}$ \\
\hline Qualified & 85.71 & 100.00 & 92.86 & 71.43 & 28.57 \\
Unqualified & 14.29 & 0.00 & 7.14 & 14.29 & 50.00 \\
Unavailable & 0.00 & 0.00 & 0.00 & 14.28 & 21.43 \\
Total & 100.00 & 100.00 & 100.00 & 100.00 & 100.00 \\
& & & & & \\
\hline
\end{tabular}

in 1997 to 100 percent in 1998 but gradually decreased since then. In 2001, although 28.57 percent qualified certificates were issued, this does not exactly reflect the actual circumstances, as there are still 21.43 percent undetermined audit certificates as represented in Table 3 by the 'unavailable' type of audit certificate.

As for the unqualified audit certificate, our findings show that only 14.29 percent were issued to the local authorities concerned in 1997 whilst none of them received the unqualified certificate in the subsequent year. In 1999, only 7.14 percent unqualified certificates were issued but the percentage appears to increase gradually to 14.29 percent and 50 percent in the years 2000 and 2001 respectively. Nevertheless, the percentage of unavailable certificates increased gradually from 0 percent to 7.14 percent and 21.43 percent for 2000 and 2001 respectively.

Details of the audit incidents mentioned in the qualified audit reports for both the municipal councils and district councils were further scrutinised and ranked as presented in Table 4. All in all, 39 incidents have been identified as hindrances for the local authorities in receiving the unqualified report either on their own or in combination with other incidents. The frequencies of audit incidents for both the municipal and district councils were added to find that the Fixed Asset Register is the most common incident with 35 occurrences. The same incident is also the main incident specified for both the municipal and district councils. Although the audit incidents of Other Receivables (13) occurred only once at the district level, it is still ranked second as it occurred quite frequently at the municipal level. Ranked in the third position is Cash Flow Statement with 12 occurrences. These top three positions in the ranking of total frequency of audit incidents appear to be similar to the ranking of frequencies of audit incidents for the municipal councils. Two audit incidents are subsequently ranked in fourth position with an overall collective frequency of 11; four incidents in fifth position (9); two incidents in sixth position (8); one incident in seventh position (6); three incidents each in eighth (5); ninth (4) and tenth positions (3); 2 incidents in eleventh position (2); and the rest occupied the last position.

\section{The Factor of Size}

Syed Soffian, Engku Ismail, Shamharir and Ayoib (2002) advocated that larger local authorities, which refers to municipal councils, are likely to have reliable internal control; thus reducing the propensity for a financial statement error. Our finding, however, appears to be otherwise. As presented in Table 4, municipal councils generated a total of 99 occurrences from 31 incidents as compared to district councils, which generated a total of 97 occurrences from only 21 incidents. Even if we discard the incident of revenue from 
Table 4

Audit Incidents Obtained from the Qualified Reports from the Local Authorities in Perlis, Kedah and Penang (1997-2001)

\begin{tabular}{|c|c|c|c|c|c|c|}
\hline \multirow[t]{2}{*}{ Audit Incidents } & \multicolumn{2}{|c|}{ Municipal Council } & \multicolumn{2}{|c|}{ District Council } & \multicolumn{2}{|c|}{ Total } \\
\hline & Freq $^{\mathrm{a}}$ & Rank & Freq & Rank & Freq & Rank \\
\hline Fixed Assets Register & 16 & 1 & 19 & 1 & 35 & 1 \\
\hline Other Receivables & 12 & 2 & 1 & 10 & 13 & 2 \\
\hline Cash Flow Statement & 7 & 3 & 5 & 7 & 12 & 3 \\
\hline Deposit and General Guarantee & 4 & 6 & 7 & 5 & 11 & 4 \\
\hline Government Grant & 1 & 9 & 10 & 2 & 11 & 4 \\
\hline Investment & 6 & 4 & 3 & 8 & 9 & 5 \\
\hline Cash in Bank & 4 & 6 & 5 & 7 & 9 & 5 \\
\hline Other Debtors & 0 & 10 & 9 & 3 & 9 & 5 \\
\hline Service Development Fund & 2 & 8 & 7 & 5 & 9 & 5 \\
\hline Account Receivables & 0 & 10 & 8 & 4 & 8 & 6 \\
\hline Work in Progress & 3 & 7 & 5 & 7 & 8 & 6 \\
\hline Accounting Policy & 0 & 10 & 6 & 6 & 6 & 7 \\
\hline Consolidated Account & 5 & 5 & 0 & 11 & 5 & 8 \\
\hline Various Payables & 5 & 5 & 0 & 11 & 5 & 8 \\
\hline Interest on Fixed Deposit & 3 & 7 & 2 & 9 & 5 & 8 \\
\hline Accrual Balance & 4 & 6 & 0 & 11 & 4 & 9 \\
\hline Tax Revenue & 4 & 6 & 0 & 11 & 4 & 9 \\
\hline General Ledger & 3 & 7 & 1 & 10 & 4 & 9 \\
\hline Account Unbalanced & 3 & 7 & 0 & 11 & 3 & 10 \\
\hline Notes to the Account & 1 & 9 & 2 & 9 & 3 & 10 \\
\hline Income \& Expenditure Statement & 1 & 9 & 2 & 9 & 3 & 10 \\
\hline Advances & 2 & 8 & 0 & 11 & 2 & 11 \\
\hline Council Fund & 2 & 8 & 0 & 11 & 2 & 11 \\
\hline Current Account & 1 & 9 & 0 & 11 & 1 & 12 \\
\hline Launching Grant & 1 & 9 & 0 & 11 & 1 & 12 \\
\hline Bank Overdraft & 1 & 9 & 0 & 11 & 1 & 12 \\
\hline Entity Accounting & 1 & 9 & 0 & 11 & 1 & 12 \\
\hline Fixed Deposit & 1 & 9 & 0 & 11 & 1 & 12 \\
\hline Revenue from SP Plaza ${ }^{\mathrm{b}}$ & 1 & 9 & 0 & 11 & 1 & 12 \\
\hline Receivables \& Accrued Interest & 1 & 9 & 0 & 11 & 1 & 12 \\
\hline Assets Received & 1 & 9 & 0 & 11 & 1 & 12 \\
\hline Adjustment Account & 1 & 9 & 0 & 11 & 1 & 12 \\
\hline Building & 1 & 9 & 0 & 11 & 1 & 12 \\
\hline Long Term Loan & 1 & 9 & 0 & 11 & 1 & 12 \\
\hline Current Assets & 0 & 10 & 1 & 10 & 1 & 12 \\
\hline Previous Year Adjustment & 0 & 10 & 1 & 10 & 1 & 12 \\
\hline Personal and Vehicle Loan & 0 & 10 & 1 & 10 & 1 & 12 \\
\hline Other Expenditure & 0 & 10 & 1 & 10 & 1 & 12 \\
\hline Deferred Revenue & 0 & 10 & 1 & 10 & 1 & 12 \\
\hline
\end{tabular}

${ }^{\mathrm{a}}$ Freq $=$ frequency

${ }^{\mathrm{b}}$ Specifically associated with the Sungai Petani Municipal Council 
SP Plaza for being the specific incident associated with the Sungai Petani Municipal Council, the municipal councils are still one-up in terms of total frequencies and nine-up in total incidents as compared to district councils. Again, with the exclusion of incident of revenue from SP Plaza, municipal councils are found to generate an average of 4 incidents per municipal council as compared to only 3 incidents per district council.

\section{CONCLUSION}

This study managed to answer several research questions. The unqualified certificate and qualified certificate appear to be the most common types of audit certificates received by the local authorities in Perlis, Kedah and Penang for the period of 1997-2001, inclusively. However, neither the adverse certificate nor disclaimer certificate was found to have been issued to any of the local authorities concerned for the same period. Despite this, our findings support the earlier study by Nailah (2001) in terms of types of audit certificates issued by the Auditor General.

The qualified audit certificate is found to dominate the type of audit certificate issued to the local authorities in Perlis, Kedah and Penang for the period from 1997-2001, with an average of 75.72 percent. Since qualified audit certificate reflect a low quality of financial reporting, our finding therefore supports the earlier studies by Nailah (2001), Emelin and Asmah (2002) and Asmah and Emelin (2004) in terms of the quality of local authorities' financial reports.

The level of audit compliance of the financial reports for all the local authorities concerned is found to have improved from 1999 onwards, reflected by the decrease in qualified audit certificates issued. All in all, 39 incidents have been discovered to contribute towards the issuance of qualified audit certificates. Those incidents include Fixed Asset Register, Other Receivables, Cash Flow Statement, Deposit and General Guarantee and Government Grant to name but a few. In our study size appears to have no significant impact either in the number of audit incidents generated or in its overall collective occurences. Thus, our finding on that score differs from Syed Soffian et al. (2002) in terms of the effect of size in reducing the propensity for financial statement errors.

There are however, a couple of limitations for this study. Firstly, our population consists of only fourteen $(n=14)$ out of 146 local authorities in Malaysia (Ministry of Housing and Local Government) and this appears to be our main obstacle in generalising our findings for the rest of local authorities in Malaysia. Secondly, we experienced difficulties in obtaining annual reports from some of the local authorities, as those financial reports are yet to be finalised. Finally, we were unsuccessful in our attempt to gather other related information from some of the local authorities leading to our inability to provide the reason(s) for the phenomena of unqualified audit certificates issued in 1998.

In conclusion, our study has successfully highlighted the causes for the issuance of qualified certificates to the local authorities in Perlis, Kedah and Penang. As the population for our study covers less than 10 percent of the total local authorities in Malaysia, we would therefore suggest for a bigger sample be selected for future studies to ascertain the quality of financial reporting among the local authorities in Malaysia.

\section{NOTES}

The authors wish to acknowledge the financial support from Universiti Utara Malaysia (UUM). We also acknowledge and thank Professor Dr Jeyapalan Kasipillai of the Faculty of Accountancy, UUM and Hazlina Hj Ali of Faculty of Quantitative Sciences, UUM for their useful comments on the paper.

\section{REFERENCES}

Asmah, A. A. \& Emelin, A. W. (2004). Audit Certificates of selected local authorities in Malaysia: A glimpse of its audit 
incidents. Paper presented at the national conference on accounting and finance (NCAF) 2004, 23-24 August 2004, Segamat, Johor.

Boyne, G. \& Law, J. (1991). Accountability and local authority annual reports: The case of Welsh District Councils. Financial Accountability \& Management, 7(4), 179-194.

Davison, R. M. (2000). Professional ethics in information system; a personal view, Communications of the AIS, 3(8).

Emelin, A.W. \& Asmah, A. A. (2002). Quality of financial reports of local authorities in Malaysia. Paper presented at the conference on financial reporting, 29-30 October 2002, Shah Alam, Selangor.

Harris, A. W. (1997). The NSW Public Sector: Towards more effective governance of government businesses. Paper presented at the Corporate Governance, Risk Management and Internal Control Conference, Australia on 29 May 1997.

Higson, A. (1996). Corporate communication: A conceptual framework for financial reporting. Retrieved February 142000 from http://les.man.ac.uk/acpa96/txt/ higson.txt (Access date: 14/2/2000)

Hyndman, N. S. \& Anderson, R. (1995). The use of performance information in external reporting: An empirical study of UK executive agencies; Financial Accountability \& Management, 11(1), February.

Ishak, T. (1989). Accoutability in public financial management (Akauntabiliti Dalam Pengurusan Kewangan Awam, Pengurusan Awam), Vol. 1, No. 2, Mei , pp. 39-49.
Kidwell, L. A. (1999). Compliance reporting decisions in municipal audits: The impact of budget variance and employment sector. Journal of Public Budgeting, Accounting and Financial Management, 11(3), 325-356.

Mahamad, T. (1998). The determinants of assessment tax collection: The Malaysian local authority experience. Unpublished PhD dissertation, University of Glamorgan.

Malaysian Approved Standards on Auditing, Malaysian Institute of Accountants, May 2001, Kuala Lumpur.

Ministry of Housing and Local Government (n. d). Statistics. Retrieved from http:// www.kpkt.gov.my

Nailah, S. (2001). Management and auditing of local authority: Towards better accountability and transparency. Paper presented at the International Forum On State And Local Governments Accounting And Reporting, 22-24 July 2001.

Nichol, E. O. \& Taylor, D. W. (2001). Accountability and performance reporting in the public accounts of the Malaysian Government. Paper presented at the International Forum On State And Local Governments Accounting And Reporting, 22-24 July 2001.

Patton, J. M. (1992). Accountability and governmental financial reporting. Financial Accountability and Management, 8(3), 165-180.

Radiah, O., Jamaliah, S. \& Noraini, M.N. (2001). Internet reporting by local authorities in Malaysia. Paper presented at the International Forum On State And Local Governments Accounting And Reporting, 22-24 July 2001. 
Syed Soffian, S. I., Engku Ismail, E. A., Shamharir, A. \& Ayoib, C.A. (2002). The determinants of financial reporting lag (FRL): The case of local governments in the state of Kedah. 